\title{
ANALISIS STUDI KEBIJAKAN PENGELOLAAN GURU SMK DALAM RANGKA PENINGKATAN MUTU PENDIDIKAN
}

\author{
Suwandi \\ Pusat Penelitian dan Kebijakan, Kementerian Pendidikan dan Kebudayaan \\ Email: suwandi_puslitjak@yahoo.com
}

\begin{abstract}
The objective of this study was to describe a model of a professional teacher management system in the era of regional autonomy to improve the quality of education in Indonesia generally, in the levels of central government, provinces, and districts in accordance with the respective roles and responsibilities. This study is categorised into a policy study. This study involved 510 teachers, 293 headmasters or vice headmasters, and 32 heads of the education departments in the level of provinces or districts. This study was conducted using survey method. This study revealed (1) the problems related to the recruitment of teachers were resulted from three reasons namely: the incompatibility of teachers qualifications with the qualifications of applicants, the formation do not meet the needs and the teachers' mutation process are not based on the teacher qualifications, (2) most of the teachers are not able to conduct scientific activities, specifically to write scientific papers, (3) the career path system cannot cover the expectations, (4) the forum of professional competence development is highly influential in the teachers' professional development, (5) the teachers competence assessment are dominated by the headmasters and (6) the supervision who had been conducted is already qualified.
\end{abstract}

Keywords: teachers, the quality of education

\begin{abstract}
ABSTRAK
Tujuan penelitian ini adalah untuk mendeksripsikan model sistem pengelolaan guru profesional di era otonomi daerah untuk meningkatkan mutu pendidikan di Indonesia secara umum, di tingkat pusat, propinsi, maupun kabupaten atau kota sesuai dengan peran dan wewenang masingmasing. Penelitian ini merupakan penelitian kebijakan. Studi ini dilakukan terhadap sampel sebanyak 510 orang guru Sekolah Menengah Kejuruan, 293 orang kepala sekolah atau wakil kepala sekolah, dan 32 orang kepala dinas pendidikan Propinsi, Kabupaten atau Kota. Penelitian ini dilaksanakan dengan menggunakan metode survei. Berdasarkan hasil penelitian dapat disimpulkan bahwa (1) permasalahan yang berkaitan dengan pengadaan guru Sekolah Menegah Kejuruan bersumber pada tiga hal yaitu ketidaksesuaian kualifikasi guru dengan kualifikasi pelamar, formasi tidak sesuai dengan kebutuhan, dan mutasi guru SMK yang tidak didasarkan pada kualifikasi guru, (2) belum seluruh guru Sekolah Menengah Kejuruan dapat melakukan kegiatan ilmiah terutama menulis karya ilmiah, (3) sistem jenjang karir yang selama ini berjalan kurang memenuhi harapan, (4) forum peningkatan kompetensi professional sangat tinggi pengaruhnya pada pengembangan profesi guru, (5) praktik penilaian kompetensi guru selama ini didominasi oleh kepala sekolah, dan (6) supervisor yang selama ini berlangsung sudah memenuhi syarat.
\end{abstract}

Kata kunci: guru, mutu pendidikan

\section{PENDAHULUAN}

Semangat otonomi daerah khususnya yang berkaitan dengan pendidikan menimbulkan beberapa masalah. Legalisasi otoritas pemerintah daerah tidak jarang kontra produktif dengan semangat pengembangan pendidikan nasional. Dalam kasus pengelolaan guru, otonomi daerah yang melahirkan dominasi pemerintah daerah dalam pengelolaan tenaga guru membuat mobilitas terhambat. Minimal terdapat dua implikasi negatif pada kondisi ini.

Mobilitas guru yang terhambat akan melahirkan psikologi kerja yang tidak nyaman. Hal ini disebabkan oleh dominasi pemerintah daerah dalam mengatur proses rekrutmen dan mobilitas karir guru. Pada gilirannya suasana tersebut sangat potensial dalam menurunkan performa kerja para guru di daerah, mengingat mobilitas karir adalah salah satu bagian dari hak 
guru. Dominasi pemerintah dalam penyediaan guru akan mengancam program peningkatan dan pemerataan kualitas pendidikan. Sangat mungkin terjadi bahwa satu daerah kekurangan tenaga kependidikan dalam bidang tertentu sementara daerah lain sumber daya yang ada cukup melimpah. Tertahannya mobilitas tenaga kependidikan suatu daerah mendorong daerahdaerah dengan tingkat kebutuhan terhadap guru yang tinggi tidak dapat mendapatkan tenaga pendidikan yang memadai. Hal ini akan menumbuhkan diskriminasi yang tajam dalam hal mutu pendidikan antar satu daerah ke daerah lain.

Guru sebagai tenaga profesional telah ditetapkan dalam UU Nomor 14 Tahun 2003, dan telah dicanangkan oleh Presiden dalam peringatan hari guru pada tahun 2005. UndangUndang Sistem Pendidikan Nasional Nomor 20 Tahun 2003 tidak menjabarkan lebih jauh seperti apa yang dimaksud dengan guru profesional. Pasal 42 ayat 1 menyatakan bahwa seorang guru harus memiliki kualifikasi minimum dan sertifikasi sesuai dengan jenjang kewenangan mengajar yang ketentuannya diatur dalam peraturan pemerintah. Dalam Peraturan Pemerintah Nomor 19 Tahun 2005 tentang Standar Nasional Pendidikan (SNP), tidak dinyatakan secara eksplisit guru sebagai jabatan dan atau pekerjaan profesional. Pasal 28 ayat 3 hanya menyatakan bahwa seorang guru sebagai agen pembelajaran diharuskan mempunyai kompetensi profesional dan kompetensi lain seperti kompetensi pedagogik, kompetensi kepribadian, kompetensi profesional, dan kompetensi sosial.

Selanjutnya dinyatakan juga bahwa setiap pendidik pada setiap jenjang pendidikan harus memiliki kualifikasi akademik minimum D4 atau sarjana pada bidang atau program pendidikan yang sesuai dengan bidang yang diajarkan atau sesuai dengan jenjang tempat mengajar dan harus pula memiliki sertifikat profesi guru (Pasal 29). Undang-undang Guru dan Dosen tahun 2005, menjelaskan kata profesional sebagai pekerjaan atau kegiatan yang dilakukan seseorang dan menjadi sumber penghasilan kehidupan yang memerlukan keahlian, kemahiran, atau kecakapan yang memenuhi standar mutu atau norma tertentu, serta memerlukan pendidikan profesi. UU Guru dan Dosen menetapkan kembali kualifikasi calon guru, yaitu lulusan program Sarjana (S1) atau program Diploma 4 (D4). Di samping itu harus memiliki sertifikat kompetensi sebagai bukti formal pengakuan terhadap kompetensi yang dimiliki dan sebagai agen pembelajaran. Sertifikat ini dapat diperoleh setelah lulus uji kompetensi yang diselenggarakan oleh satuan pendidikan yang terakreditasi atau lembaga sertifikasi.

Selain memiliki ijasah S1 dan D4 serta sertifikat kompetensi, seseorang yang hendak menjadi guru juga harus memiliki sertifikat profesi. Sertifikat ini adalah bukti formal sebagai pengakuan kewenangan bagi yang telah memiliki kualifikasi akademik minimal dan sertifikat kompetensi. Sertifikat ini dikeluarkan oleh perguruan tinggi yang memiliki program pengadaan tenaga kependidikan yang terakreditasi minimal B. Proses sertifikasi dalam UU Guru dan Dosen tersebut terkesan sangat birokratis dan menjadi lahan baru kolusi, korupsi, dan nepotisme dalam penerapannya, menggabungkan program sertifikasi kompetensi dan profesi menjadi hal yang sangat dibutuhkan. Pendidikan profesi guru menghasilkan atau mengeluarkan sertifikat profesi.

Sekolah Menengah Kejuruan sebagai salah satu lembaga pendidikan yang mempunyai misi menyiapkan tenaga kerja tingkat menengah yang mampu mengisi lapangan kerja dan berkualitas profesional diharapkan mampu berperan sebagai alat unggulan bagi industri-industri di Indonesia dalam menghadap Masyarakat Ekonomi Asean (MEA) tahun 2015. Berdasarkan pada latar belakang masalah di atas, maka dapat diidentifikasi beberapa permasalahan yang terkait dengan deskripsi model pengembangan profesionalisme guru sekolah Menegah Kejuruan adalah sebagai berikut ini: (1) apakah sertifikasi profesi guru cukup sekali dan berlaku seumur hidup? (2) Apakah ketentuan yang 
mewajibkan guru untuk memperbaharui sertifikat kewenangan mengajar secara berkala melalui uji kompetensi produktif diperlukan?

(3) Bagaimana agar promosi dan peningkatan kualitas guru-guru SMK dapat diwujudkan?

(4) Bagaimana menemukan model registrasi guru yang sederhana dan tidak mempersulit serta bebas dari KKN? (5) Bagaimana sebaiknya model pendidikan guru profesional yang diharapkan?

Mutu pendidikan adalah gambaran dan karakteristik menyeluruh dari suatu barang atau jasa yang menunjukkan kemampuan dalam memuaskan kebutuhan yang diharapkan atau yang tersirat. Dalam konteks pendidikan, pengertian mutu mencakup input, proses, dan output pendidikan (Depdiknas, 2003). Dalam peningkatan mutu pendidikan melalui manajemen berbasis sekolah (MPMBS). Depdiknas (2003) menyatakan bahwa input pendidikan adalah segala sesuatu (sumber daya) yang harus tersedia karena dibutuhkan untuk berlangsungnya proses. Sumber daya yang dimaksud dapat berupa sumber daya manusia: kepala sekolah, guru, karyawan, siswa, penjaga sekolah juga perangkat lain seperti struktur organisasi sekolah, peraturan sekolah, deskripsi tugas, dan rencana program. Proses pendidikan dapat berupa proses pengambilan keputusan, proses pengelolaan kelembagaan, proses pengelolaan program, proses belajar mengajar, dan proses monitoring dan evaluasi. Proses dikatakan bermutu tinggi apabila harmonis, sehingga mampu menciptakan situasi belajar yang kondusif, menyenangkan, mendorong motivasi dan minat belajar, dan memberdayakan peserta didik. Output pendidikan merupakan kinerja sekolah, yang dapat diukur dari kualitas, efektivitas, produktivitas, efisiensi, inovasi, kualitas kehidupan kerja, dan moral kerja. Sekolah dikatakan berkualitas tinggi jika pencapaian prestasi akademik yang tinggi. Prestasi akademik berupa ulangan umum, EBTA, EBTANAS, karya ilmiah, lomba akademik, dan prestasi nonakademik, seperti kesopanan, keimanan dan ketaqwaan (IMTAQ), kejujuran, olahraga, kesenian keterampilan, dan prestasi pada kegiatan ekstrakurikuler lain. Pada saat ini, secara umum pendidikan di tanah air masih menghadapi masalah. Masalah pertama adalah tingkat pemerataan pendidikan yang masih rendah; kedua, rendahnya kualitas manajemen pendidikan; dan ketiga, rendahnya mutu pendidikan.

Hasil penelitian yang dilakukan beberapa lembaga internasional sebagaimana dipaparkan dalam Tabel 1 berikut ini menggambarkan bahwa mutu pendidikan di Indonesia masih sangat rendah (Pusat penelitian pendidikan UM, 2003).

Tabel 1. Gambaran Kualitas Pendidikan Indonesia Berdasarkan Berbagai Temuan Penelitian

\begin{tabular}{|c|c|c|}
\hline No & Organisasi Peneliti & Temuan Penelitian \\
\hline 1. & $\begin{array}{l}\text { International Educational } \\
\text { Achievement (IEA) tahun } 2000\end{array}$ & $\begin{array}{l}\text { a. Kemampuan membawa siswa SD berada pada posisi ke-38 dari } 38 \\
\text { negara peserta studi. } \\
\text { b. Kemampuan matematika siswa SLTP secara berurutan menduduki } \\
\text { peringkat ke-39 dan ke-40 dari } 42 \text { negara peserta. }\end{array}$ \\
\hline 2. & $\begin{array}{l}\text { Programme for International } \\
\text { Student Assessment (PISA) } 2003\end{array}$ & $\begin{array}{l}\text { a. Indonesia menduduki peringkat } 38 \text { dari } 41 \text { Negara yang di survei untuk } \\
\text { bidang IPA } \\
\text { b. Indonesia menduduki peringkat ke- } 39 \text { dari } 41 \text { Negara yang di survei } \\
\text { untuk bidang matematika dan kemampuan membaca }\end{array}$ \\
\hline 3. & $\begin{array}{l}\text { Institut for Management } \\
\text { Development (IMD) tahun } 1999\end{array}$ & $\begin{array}{l}\text { c. Dalam pengadaan insinyur, Indonesia berada pada posisi ke-34 dari } 36 \\
\text { negara peserta studi. } \\
\text { d. Dalam kerjasama antara industri dengan perguruan tinggi, dan } \\
\text { kerjasama penelitian antara industri dengan perguruan tinggi, Indonesia } \\
\text { menempati juru kunci - peringkat } 46 \text { dari } 46 \text { negara peserta studi. }\end{array}$ \\
\hline 4. & UNDP (tahun 1999) & $\begin{array}{l}\text { e. Dalam indeks pembangunan manusia Indonesia, manusia Indonesia } \\
\text { berada pada posisi ke-105 dari } 108 \text { negara peserta studi. }\end{array}$ \\
\hline 5. & $\begin{array}{l}\text { Word Competitiveness Yearbook } \\
\text { (2015) pada tahun } 1977 \text { sampai } \\
\text { dengan } 1999\end{array}$ & $\begin{array}{l}\text { f. Daya saing Indonesia pada tahun } 1997 \text { berada pada posisi ke-39,dan } \\
\text { pada } 1999 \text { merosot ke posisi } 46 \text { dari } 47 \text { negara peserta studi. }\end{array}$ \\
\hline
\end{tabular}


Rendahnya mutu pendidikan di tanah air juga tampak dari rendahnya kualitas output dan outcome pendidikan. Puspendik (2015) menyatakan bahwa sistem pendidikan yang sekarang berjalan pada umumnya belum sesuai dengan kualitas yang diharapkan. Penilaian ini didasarkan pada ukuran kemampuan peserta didik dalam menjawab Ujian Nasional Sekolah Menengah Kejuruan yang rendah. Indikator lain adalah keterampilan yang menjadi ciri khas pendidikan kejuruan, keimanan, rasa tanggung jawab, dan budi pekerti yang belum mendapat perhatian secara memadai. Di samping itu, semakin meningkatnya jumlah pengangguran terdidik, juga menjadi indikator rendahnya kualitas pendidikan.

Indikasi rendahnya mutu pendidikan di atas diduga karena rendahnya kualitas yang meliputi program pendidikan (kurikulum dan pembelajaran) yang berlaku saat ini, administrasi dan manajemen sekolah, tenaga kependidikan yang dimiliki sekolah saat ini, input dan pengembangan peserta didik, sarana dan prasarana pendidikan, dan rendahnya kualitas partisipasi masyarakat dalam dunia pendidikan. Di samping itu, diantara penyebab rendahnya mutu pendidikan yaitu kebijakan-kebijakan pendidikan yang dikeluarkan pemerintah tidak sejalan dengan hal-hal yang berkaitan untuk peningkatan mutu pendidikan (Puspendik, 2015). Hasil penelitian Puslitdik lemlit UM (2003) tentang mutu pada pendidikan Sekolah Menengah Kejuruan (laporan akhir monitoring dan evaluasi independent proyek peningkatan mutu pendidikan Menengah Kejuruan, 2003) dapat meningkatkan mutu pembelajaran di sekolah, prestasi belajar siswa, keberlanjutan partisipasi masyarakat, dan jumlah calon siswa yang mendaftar pada sebagian besar SMK meningkat, juga dapat meningkatkan daya tampung pada sebagian Sekolah Menengah Kejuruan di daerah tertinggal.

Faktor-faktor yang berkaitan dengan mutu pendidikan SMK diantaranya adalah: kurikulum dan pembelajaran, administrasi dan manajemen sekolah, tenaga kependidikan, peserta didik, sarana dan prasarana pendidikan, dan peran serta masyarakat.

Guru, kepala sekolah, dan pengawas pendidikan adalah tenaga profesional. Sebagai tenaga profesional karena pekerjaan yang: (1) menuntut keahlian dan keterampilan yang memerlukan pendidikan dan pelatihan yang cukup; (2) masuk dalam kelompok masyarakat (organisasi profesi); (3) diikat dengan kode etik profesi; (4) harus mampu mengembangkan dunia profesi.

Kondisi dunia keguruan masih sangat suram. Suramnya dunia keguruan tersebut, ditunjukan oleh Akbar (2003) bahwa guru masih banyak mengalami kesulitan dalam mengembangkan dunianya, diantaranya adalah kesulitan mengembangkan kurikulum menjadi bahan ajar, kurang mampu mengembangkan media pembelajaran, praktik pembelajaran over kognitif, dan praktik pembelajaran yang kurang bervariasi. Di samping itu, penghasilan guru masih sangat rendah. Guru harus merangkap pekerjaan administratif yang berakibat pada kinerja yang kurang optimal. Akbar (2003) juga menunjukkan bahwa guru-guru masih mengalami kesulitan untuk mengembangkan pembelajaran terpadu, meskipun memiliki kemampuan yang potensial untuk dikembangkan dengan pembinaan yang intensif. Jadi, guru di tanah air ini masih relatif kurang mampu mengembangkan dunia sendiri dan masih cenderung memposisikan diri menjadi tenaga teknis. Padahal Fayer, dkk (1984) menjelaskan guru-guru dan tenaga non guru yang bermutu adalah yang senantiasa mau dan mampu melakukan pembaharuan dan perbaikan dunianya sendiri secara kontinyu.

Apabila ditinjau dari tenaga non kependidikan, menurut hasil studi pendahuluan, sebagian besar Sekolah Menengah Kejuruan belum memiliki tenaga administratif tersendiri dan teknisi yang memiliki keahlian khusus. Bagi sekolah yang sudah mempunyai tenaga administrasi kemampuannya masih sangat terbatas, peralatan kerja yang sangat kurang; teknisi yang dipekerjakan juga sebagian besar masih lulusan Sekolah Dasar, sehingga belum 
dapat mengembangkan kemampuan profesional di bidangnya. Para tukang kebun dan penjaga sekolah juga kurang mampu mengembangkan dunianya sendiri misalnya mengembangkan taman, menata lingkungan menjadi lebih asri dan nyaman. Di sisi lain, kemampuan sekolah untuk mengelola tenaga non kependidikan (rekrutmen, penerimaan, pembinaan) juga masih sangat kurang.

Dalam MPMBS Depdiknas (2003: 24) disebutkan bahwa pengelolaan ketenagaan mulai dari analisis kebutuhan, perencanaan, rekrutmen, pengembangan, hadiah dan sanksi, hubungan kerja, sampai evaluasi kinerja tenaga kerja sekolah dapat dilakukan oleh sekolah kecuali untuk pegawai negeri. Dari waktu ke waktu, pemerintah telah mengeluarkan kebijakankebijakan untuk memperbaiki kualitas pendidikan di tanah air. Di antara kebijakan-kebijakan itu adalah kebijakan tentang: pemberantasan buta huruf, pendidikan masyarakat dan pendidikan luar sekolah; kegiatan inovasi pendidikan seperti proyek PAMONG, pendidikan pramuka untuk transmigrasi, pusat kegiatan belajar, kuliah kerja nyata, proyek pengembangan sistem informasi pendidikan; proyek percobaan radio pendidikan; proyek STM pembangunan, proyek perintis sekolah pembangunan, proyek pendidikan guru dan orang tua asuh bagi anak kurang mampu (Gunawan, 1995).

Di era tahun 2000an, arah kebijakan pemerintah di bidang pendidikan menuju pada perluasan dan pemerataan kesempatan pendidikan yang bermutu; pengembangan kemampuan akademik dan profesional tenaga kependidikan, pembaharuan kurikulum, pemberdayaan lembaga pendidikan, pembaharuan dan pemantapan sistem pendidikan, peningkatan kualitas lembaga pendidikan, pengembangan kualitas sumber daya manusia sedini mungkin, penguasaan pengembangan dan pemanfaatan teknologi, dengan sasaran peningkatan angka partisipasi, kesamaan memperoleh pendidikan bermutu, organisasi sekolah yang demokratis, transparan, efisien dan accountable.

Syarat-syarat profesional yang menduduki tempat penting, yaitu: (a) menguasai bidang studi yang diajarkan; (b) menguasai pedagogi; (c) mengetahui inti bidang studi yang diajarkan; (d) mampu mengajarkan keahlian kepada murid yang memiliki berbagai latar perkembangan; (e) mampu untuk menggunakan keterampilan diagnostik untuk membantu murid yang mengalami masalah akademik; (f) mampu memahami perubahan yang terjadi pada murid, dalam perubahan fisik, sosial, psikologis maupun intelektual. Di samping itu guru profesional juga harus mampu: (a) mengambil keputusan pendidikan dengan judgment yang tepat; (b) menguasai teknik memotivasi murid; (c) menguasai teori dan keterampilan manajemen kelas; (d) menjadi evaluator kemajuan anak didik; (e) menjadi evaluator program pendidikan; (g) memperjuangkan kepentingan murid dalam proses perkembangannya dan (h) melakukan refleksi dan juga perbaikan dalam praktik profesional.

\section{METODE}

Penelitian ini merupakan penelitian kebijakan berupa studi yang mengarah pada deskripsi peningkatan efisiensi dan efektifitas pengelolaan sebagai konsekuensi implementasi otonomi daerah yang telah dilaksanakan. Studi ini dilakukan terhadap guru SMK, kepala sekolah, dan dinas pendidikan di 19 propinsi dengan sampel sebanyak 510 orang guru, 293 orang kepala sekolah atau wakil kepala sekolah, dan 32 orang kepala dinas pendidikan Propinsi, Kabupaten dan Kota ditambah dengan 200 orang responden sebagai sampel uji coba. Penelitian menggunakan metode survei dengan langkah sebagai berikut: (1) pengumpulan informasi dan kajian literatur, (2) penyusunan desain model sistem pengelolaan guru dan instrumen, (3) pengumpulan data lapangan, (4) analisis data, (5) penyusunan laporan.

\section{HASIL DAN PEMBAHASAN}

Secara umum dari segi cakupan aspek administrasi guru, Dinas Pendidikan Kabupaten atau Kota menempati urutan pertama dalam hal 
kewenangan administrasi, kecuali pada aspek pendistribusian dan pengembangan profesi. Responden berkeinginan sekolah diberikan kewenangan yang pertama. Sekolah diharapkan diberi kesempatan kewenangan kedua pada aspek promosi, perlindungan, penghargaan, dan perencanaan kebutuhan. Dinas Pendidikan Pusat berada pada urutan kedua pada aspek rekrutmen dan usulan penambahan. Sedangkan Dinas Pendidikan Propinsi perlu diberi kewenangan dengan urutan kedua pada aspek mutasi, selebihnya berada pada urutan berikutnya. Lembaga Pendidikan Teknologi dan Kejuruan (LPTK) secara signifikan tidak dipandang sebagai lembaga yang memiliki kewenangan administrasi.

Mayoritas responden secara signifikan berpendapat bahwa permasalahan mengenai pengadaan guru bersumber pada 3 hal yaitu ketidaksesuaian kualifikasi guru dengan kualifikasi pelamar sebesar 74,5\%, formasi tidak sesuai dengan kebutuhan sebesar 79,0\% dan mutasi guru yang tidak didasarkan pada kualifikasi guru sebesar 72,0\%. Adapun masalah keuangan sebagai penyebab, pendapat responden disetujui oleh $61,10 \%$. Adapun materi tes seleksi guru, ternyata responden menyetujui materi tes yang selama ini digunakan tergabung dengan tes khusus bidang studi dan ketrampilan mengajar; tes bidang kejuruan (produktif). Secara umum responden setuju bahwa materi tes menjadi guru meliputi Pengetahuan Umum, Bahasa Indonesia, Bahasa Inggris, Bidang Studi, Keterampilan mengajar, bakat dan Potensi akademik, namun sejumlah $85,8 \%$ responden tidak setuju jika data indeks prestasi dan akreditasi menjadi satu-satunya alat tes seleksi

Pengenalan pada semua konsep indeks kompetensi guru dalam pengelolaan guru ternyata didukung lebih dari $50 \%$ responden, kecuali kemampuan mengajarkan materi subyek dengan bahasa Inggris dan kemampuan untuk menggunakan Information and Communications Technology (ICT) dalam proses pembelajaran. Komponen kompetensi pedagogik dinyatakan bahwa pemahaman guru terhadap peserta didik, kemampuan merancang dan melaksanakan pembelajaran, kemampuan mengevaluasi proses dan hasil belajar serta kemampuan untuk mengembangkan peserta didik mengaktualisasi diri merupakan komponen paling menentukan. Tentang kompetensi sosial guru kemampuan bergaul dan berkomunikasi dengan masyarakat didukung sebesar $59,8 \%$ dengan peserta didik sebesar $77,8 \%$, dengan sesama guru sebesar $68,3 \%$. Sedangkan guru secara umum memiliki rasa empati dan toleransi kepada orang lain didukung sebanyak $66,8 \%$ dan memiliki kemampuan bekerjasama sebanyak $74,0 \%$. Kompetensi kepribadian guru yang terpenting adalah aspek moralitas dan tanggung jawab terlihat dari jawaban responden yang mencapai lebih dari 90\%. Penampilan juga dianggap penting tetapi tidak prioritas.

Mengenai butir-butir kegiatan berkaitan dengan profesi secara umum banyak guru yang telah melakukan kegiatan berkaitan dengan profesi secara lengkap dengan didukung lebih dari $75 \%$, kecuali kemampuan menulis karya ilmiah dan pengembangan karya profesional yang hanya $71,6 \%$, yang menunjukan bahwa belum seluruh guru dapat melakukan kegiatan ilmiah terutama menulis karya ilmiah. Banyak guru yang merasa kesulitan untuk menulis karya ilmiah. Hal tersebut dikarenakan bidang keilmuan guru SMK yang tidak dikembangkan. Hal ini berdampak pada materi pembelajaran yang cenderung menggunakan standar lama, sehingga perkembangan dunia teknologi saat ini tidak dapat dikuasai. Bidang keilmuan guru SMK tidak dapat terfokus pada bidang khusus, oleh karenanya penulisan karya ilmiah yang telah dilaksanakan hanya berdasarkan pada proses pembelajaran.

Komponen kinerja guru terdiri dari keteladanan, konsistensi antara sikap dan perilaku tutur kata, tanggung jawab dalam melaksanakan tugas, kemampuan dalam berkomunikasi, kedisplinan, kemampuan untuk mengembangkan diri, penguasaan bidang studi atau disiplin ilmu kejuruan yang menjadi tugas, Di samping itu komponen kinerja guru juga meliputi kemampuan menerjemahkan kurikulum bidang studi dalam bahan ajar yang harus disampaikan kepada siswa, penguasaan metode 
keilmuan dari bidang studi yang menjadi tugasnya, penguasaan konteks bahan ajar dengan kehidupan masyarakat dan teknologi, penguasaan keterkaitan bidang studi dengan bidang studi lain (keluasan wawasan bahan ajar), pemahaman dan pengenalan terhadap karakteristik peserta didik, penguasaan teori pendidikan dan pembelajaran sebagai landasan dalam pelaksanaan tugas, penguasaan kemampuan dan keterampilan pembelajaran yang mendidik, kreativitas dan inovatif dalam pelaksanaan tugas profesional yang ditawarkan melalui instrumen disetujui sebagai responden dalam kategori penting dan sangat penting, kecuali komponen kemampuan dalam mencapai prestasi keguruan yang terukur (pembimbing LKIR, Olimpiade MIPA, dan yang sejenis) dinilai sangat penting didukung hanya oleh $33,7 \%$. Selebihnya menyatakan cukup dan kurang penting.

Sementara itu, aspek tanggung jawab dalam pelaksanaan tugas merupakan komponen kinerja guru yang utama dinilai sangat penting oleh $89,4 \%$ responden. Jenjang karir profesi guru dalam sistem kepegawaian, responden memiliki pandangan yang hampir seragam yaitu bahwa sistem jenjang karir yang selama ini berjalan berada pada kategori kurang memenuhi harapan dengan angka dukungan antara 29,0\% sampai $50,2 \%$ dari keseluruhan responden. Sementara itu, ketersediaan reward khusus bagi guru berprestasi dan ketersedian punishment khusus bagi guru yang tidak berprestasi dinilai tidak signifikan dengan presentase bobot nilai yang telah memenuhi harapan hanya $9,0 \%$ dan $4,4 \%$, secara lebih detail data menunjukan bahwa kejelasan pola karir guru, gradasi kompetensi, rumusan kompetensi profesional berdasarkan jenjang karir, standar penilaian kompetensi profesional untuk penetapan jenjang karir dan keteradilan antara prestasi dengan karir guru cenderung dianggap kurang memenuhi.

Mengenai sistem penggajian selama ini masih dianggap belum memenuhi dan kurang sesuai dengan beratnya kerja dan tanggung jawab guru SMK, terutama keterlaksanaan sistem jaminan sosial bagi profesi guru yang dinilai tidak memenuhi harapan dengan angka dukungan mencapai 30,4\%.

Forum peningkatan kompetensi profesional, seperti KKC dan MGMP cenderung dinilai tinggi dan sangat tinggi pengaruhnya pada pengembangan profesi guru dengan angka dukungan $51,9 \%$ dan $28,3 \%$. Kehadiran organisasi seperti PGRI, FGB, FGI, FORGAS, dan PII cenderung dinilai rendah dan cukup urgensinya bagi pengembangan profesi guru. Data ini juga menunjukan bahwa respons, aspirasi dan tingkat partisipasi guru dan tenaga kependidikan dalam upaya pengembangan profesi dinilai belum memuaskan karena cenderung dinilai rendah dan cukup. Sebagian besar responden yaitu $67,9 \%$ setuju dengan implementasi konsep indeks kualifikasi guru dalam rangka pengelolaan dan peningkatan mutu guru. Terlihat bahwa pendapat responden tentang kualifikasi guru memiliki determinasi yang sangat tinggi. Menurut responden, guru yang memiliki ijazah lebih rendah dari standar persyaratan cenderung dinilai 1, guru yang memiliki ijazah sesuai standar persyaratan tetapi mengampu di bidang studi di luar kewenangannya cenderung dinilai 2 dan guru memiliki ijazah sesuai dengan persyaratan dan mengajar sesuai kewenangannya cenderung dinilai 4.

Kepemilikan ijazah tambahan setingkat atau dua tingkat di atas persyaratan, sesuai dengan bidang ajar maupun tidak, cenderung tidak mengubah penilaian terhadap kualifikasi sesuai persyaratan. Dalam konteks ini, guru kurang menganggap penting ijazah tambahan terhadap sistem penilaian guru terutama ijazah tambahan yang di luar bidang studi. Angka maksimal 4 tetap cenderung diberikan kepada guru yang memenuhi ijazah sesuai persyaratan dan mengajar sesuai bidang ilmu. Sebanyak $68,1 \%$ responden menyetujui bahwa dalam rangka pengelolaan dan peningkatan mutu guru SMK digunakan konsep indeks kompetensi guru. Para guru juga menyatakan hampir keseluruhan sumber penilaian yang ditawarkan dalam instrumen ini cenderung tidak ditolak, 
kecuali penilaian dari Dinas Pendidikan Propinsi yang cenderung dianggap tidak perlu masuk dalam unsur penilaian.

Data hasil penelitian juga menunjukan bahwa praktik penilaian kompetensi guru yang selama ini berlangsung didominasi oleh penilaian dari supervisor dan kepala sekolah. Hasil penelitian juga menunjukan bahwa kondisi realisasi di lapangan belum dilaksankan secara optimal penilaian guru yang benar-benar dapat menilai profesi dan kompetensi guru.

Secara umum hampir semua lembaga yang diusulkan pada penelitian ini tidak ditolak keterlibatannya dalam penilaian kompetensi guru, kecuali BSNP yang cenderung dinilai tidak perlu terlibat dalam koordinasi antar lembaga. Berbeda dengan pendapat guru, kepala sekolah menilai agak ragu-ragu terhadap PGRI untuk dimasukan dalam lembaga konsorsium dalam penilaian indek kompetensi guru dengan memberi skor yang relatif rendah, hal ini karena dirasakan sekarang ini, PGRI tidak independen lagi dengan dimilikinya lembaga-lembaga pendidikan sendiri yang bersaing dengan lembaga pendidikan lain, hal ini dimungkinkan terjadi ketidakobjektifan PGRI dalam menilai indek kompetensi guru di luar lembaga pendidikan dalam koordinasinya.

Untuk masalah supervisi guru, $61,2 \%$ responden cenderung menganggap bahwa personil supervisor yang selama ini berlangsung sudah memenuhi syarat, menurut para guru komposisi personil supervisor tersebut $83,0 \%$ adalah pengawas dari Dinas Pendidikan 77,6\% adalah kepala sekolah dan $45,5 \%$ adalah guru senior. Di samping itu, supervisor yang ideal adalah terdiri dari pengawas, kepala sekolah dan guru senior sebagai satu kesatuan. Hampir seluruh kualitas kegiatan supervisi juga cenderung dinilai cukup tinggi dengan skor 3 melalui angka dukungan di atas $40 \%$, kecuali keteladanan supervisor dengan nilai sangat beragam yaitu sangat rendah $19,6 \%$, rendah $28,4 \%$ tinggi $29,1 \%$ dan sangat tinggi $22,0 \%$ dengan $t$ table 4,54 . Data menunjukan bahwa sekitar $47,7 \%$ responden menilai bahwa frekuensi supervisor dalam mendatangi dan mengamati guru mengajar berada dalam kategori kurang, sedang antara $10,3 \%$ dan $27,9 \%$ responden menilai bahwa frekuensinya cukup. $49,5 \%$ responden menilai bahwa kegiatan supervisi memotivasi memberikan saran yang operasional dan komunikasi yang terbuka berada dalam kategori sangat baik. Namun, sekitar $22,5 \%$ responden juga menilai bahwa supervisor kurang memberitahukan komponenkompenen penilaian.

Dalam sistem pengelolaan guru di era otonomi daerah, peranan utama pemerintah pusat seharusnya mengembangkan sistem kepegawaian guru secara nasional yang meliputi rumusan standar pengajaran minimum, skala gaji minimal, petunjuk kenaikan pangkat guru serta petunjuk pemberian insentif. Dinas Pendidikan tingkat Propinsi bertanggung jawab memastikan bahwa pemerintah Kabupaten mampu untuk memenuhi kewajiban hukum menyediakan pendidikan Sekolah Menengah Kejuruan yang berkualitas. Dinas Pendidikan tingkat Propinsi diharuskan memberikan saran pada pemerintah Kabupaten atau Kota tentang peningkatan sekolah dan pengembangan guru serta memastikan bahwa guru dapat ditugaskan lintas kabupaten apabila diperlukan.

Pemerintah Kabupaten adalah yang bertanggung jawab dalam pengangkatan dan pengiriman guru serta pemberian gaji pokok (standar minimum nasional) dan insentif tambahan lain. Pemerintah Kabupaten atau Kota bertanggung jawab dalam mengawasi kinerja guru, memastikan bahwa guru memiliki akses untuk pengembangan profesional yang berkenaan dengan kegiatan sekolah. Implementasi manajemen pendidikan berbasis sekolah (MBS) dan pembentukan dewan pendidikan tingkat Kabupaten atau Kota mengubah makna akuntabilitas guru dan sistem penggajian. Perubahan ini berarti bahwa keputusan tentang sumber daya sekolah dan tujuan pendidikan di sekolah dibuat oleh yang memahami lingkungan sekolah. Di sisi lain, perubahan itu menciptakan beban yang berat bagi guru, kepala sekolah, 
komite sekolah dan orang tua yang harus bekerja bersama untuk meningkatkan prestasi siswa.

Secara umum ditemukan bahwa daerah belum memiliki kesiapan mengelola guru dalam bentuk kebijakan atau peraturan daerah. Oleh karena itu, perlu ada keberanian pemerintah daerah membuat kebijakan untuk pengelolaan guru sesuai dengan batas-batas kewenangan. Berdasar uraian di atas beberapa hal yang terkait dengan pengelolaan guru di era otonomi daerah, menyangkut: Diberlakukannya sistem desentralisasi, pemerintah Kabupaten atau Kota bertanggung jawab mengangkat semua guru untuk sekolah negeri selain madrasah. Pemerintah Kabupaten atau Kota melalui Departemen Dalam Negeri bertanggung jawab dalam pengangkatan guru dengan melibatkan dewan pendidikan setempat. Dalam hal ini pemerintah Kabupaten atau Kota seharusnya wajib berperan lebih besar dalam penyeleksian (rekrutmen) dan pengangkatan guru. Masyarakat wajib diikutsertakan dalam menentukan kriteria penyeleksian dan dalam penyeleksian guru-guru dan kepala sekolah.

Selanjutnya beberapa rekomendasi terkait dengan sistem rekrutmen dan penempatan guru adalah sebagai berikut: (a) Kebijakan yang berlaku tentang penerimaan (rekrutmen) guru dipertahankan sesuai dengan prosedur rekruitmen pegawai negeri sipil; (b) Sistem pengangkatan guru diatur dan menjadi kewenangan pemerintah pusat dan penempatan ke daerah didasarkan pada kebutuhan sekolah dan perencanaan daerah; (c) Sistem mutasi guru dalam Kabupaten atau Kota menjadi kewenangan pemerintah kabupaten atau kota; (d) Sistem mutasi guru antar kabupaten atau kota di dalam Propinsi menjadi kewenangan pemerintah Propinsi; (e) Sistem mutasi guru antar Propinsi menjadi kewenangan pemerintah pusat; (f) Guru-guru baru dapat diwajibkan bertugas di daerah-daerah khusus untuk masa kerja sekurang-kurangnya selama 2 tahun; (g) Perlu diadakan ketentuan untuk memindahkan guru antar sekolah (rotasi) sesudah masa yang disepakati; (h) Pengangkatan jumlah guru perlu mempertimbangkan jumlah kebutuhan minimal guru pada setiap sekolah dan jumlah murid.

Hasil evaluasi tentang uji kompetensi guru SMK, yaitu: (a) Pemerintah pusat perlu menetapkan kebijakan program peningkatan kualifikasi guru melalui pendidikan lanjut melalui sekolah profesi; (b) Pemerintah daerah (Propinsi dan Kabupaten atau Kota) perlu menetapkan kebijakan program peningkatan kompetensi profesi guru melalui: (1) Pendidikan Profesi Guru (PPG), (2) pendidikan dan pelatihan untuk peningkatan kompetensi, (3) pertukaran guru dan kepala sekolah, dan (4) pemagangan; (c) program peningkatan kompetensi guru dilakukan oleh konsorsium independen melalui koordinasi antar lembaga yang melibatkan LPTK, LPMP, P3G, Dinas Pendidikan Propinsi, dan Dinas Pendidikan Kabupaten atau Kota.

Berdasarkan hasil evaluasi sistem kinerja guru, didapatkan hasil sebagai berikut: (a) Sistem penggajian guru perlu didasarkan pada indeks kompetensi guru; (b) Sistem jenjang karir guru perlu ditinjau kembali dengan mempertimbangkan merit system, yaitu sistem penghargaan guru berdasarkan kinerja; (c) Sistem promosi dalam jenjang karir guru perlu didasarkan indeks kompetensi melalui mekanisme yang transparan dan akuntabel; (c) Sistem jenjang karir guru perlu diikuti dengan sistem reward dan punishment yang proporsional. Berdasarkan hasil evaluasi pengembangan organisasi profesi, item penting yang harus segera dilaksanakan adalah sebagai berikut: (a) Lembaga musyawarah guru seperti KKG dan MGMP yang merupakan lembaga yang mendapat respon paling baik dari guru. Lembaga-lembaga ini perlu direvitalisasi sehingga mampu memerankan peran sebagai organisasi profesi yang mempunyai tujuan pokok untuk meningkatkan kompetensi guru; (b) Pengembangan lembaga musyawarah guru menjadi organisasi profesi guru perlu didukung oleh kebijakan pemerintah daerah, sedangkan pemerintah pusat perlu memberikan teknis supaya organisasi profesi guru mampu menjadi tulang punggung lembaga sertifikasi dengan 
mensinergikan peranan LPTK, LPMP, dan organisasi profesi bidang keilmuan; (c) Organisasi profesi guru merupakan bagian yang tak terpisahkan dalam pengelolaan guru, sehingga organisasi profesi perlu dikembangkan dalam kerangka penjaminan mutu pendidikan.

Hal yang mendasar terkait dengan sistem penilaian guru, adalah sebagai berikut: (a) Perlu dibuat indeks kualifikasi guru berdasarkan kesesuaian ijazah dengan standar persyaratan minimal dan bidang ajar, peta indeks kualifikasi guru tersebut selanjutnya dapat dijadikan dasar kebijakan penggarangan terutama untuk studi lanjut dalam rangka memenuhi kualifikasi guru; (b) Perlu dibuat indeks kompetisi guru yang meliputi indeks kompetensi bidang studi, pedagogik, kepribadian dan sosial, seluruh aspek penyusun indeks tersebut diperoleh melalui suatu penilaian yang transparan dan akuntabel, meliputi penilaian oleh diri sendiri, siswa, teman sejawat, supervisor, kepala sekolah, MGMP, Dinas Pendidikan Kabupaten atau Kota dan organisasi profesi; (c) Untuk menjamin pengembangan kemampuan guru sesuai dengan tuntutan zaman, proses sertifikasi perlu diperbaharui oleh guru setiap 5 tahun; (d) Proses mekanisme penilaian guru oleh komponen-komponen di atas selalu mengacu pada standar yang dikembangkan oleh BSNP.

Pemahaman terkait dengan supervisi guru, hal yang perlu diperhatikan adalah sebagai berikut: (a) Supervisor yang ideal terdiri dari pengawas, kepala sekolah dan guru senior sebagai satu kesatuan; (b) Untuk meningkatkan kualitas dari supervisi perlu memperhatikan hal - hal sebagai berikut: keteladanan supervisor, frekuensi kunjungan supervisor ke sekolah, dan memotivasi dengan memberi saran yang operasional serta komunikasi yang terbuka; (c) Supervisi juga dimaksudkan untuk meningkatkan kualitas guru melalui pengamatan dan pemodelan proses belajar mengajar, oleh karena itu kebijakan tentang supervisi hendaknya menghindari kesan mengadakan penilaian terhadap guru.

\section{SIMPULAN}

Berdasarkan pembahasan di atas, maka dapat ditarik kesimpulan sebagai berikut: (1) Permasalahan yang berkaitan dengan pengadaan guru bersumber pada tiga hal yaitu ketidaksesuaian kualifikasi guru dengan kualifikasi pelamar, formasi tidak sesuai dengan kebutuhan, dan mutasi guru yang tidak didasarkan pada kualifikasi guru; (2) Belum seluruh guru dapat melakukan kegiatan ilmiah terutama menulis karya ilmiah, banyak guru yang merasa kesulitan untuk menulis karya ilmiah; (3) Sistem jenjang karir yang selama ini berjalan kurang memenuhi harapan. Ketersediaan reward khusus bagi guru yang berprestasi dan ketersediaan punishment khusus bagi guru yang tidak berprestasi dinilai tidak signifikan dengan persentase; (4) Forum peningkatan kompetensi professional, seperti KKC dan MGMP sangat tinggi pengaruhnya pada pengembangan profesi guru. Kehadiran organisasi seperti PGRI, FGB, FGI, dan FORGAS serta organisasi keilmuan cenderung dinilai rendah urgensinya bagi pengembangan profesi guru; (5) Praktik penilaian kompetensi guru yang selama ini berlangsung didominasi oleh penilaian dari supervisor dan kepala sekolah; (6) Supervisor yang selama ini berlangsung sudah memenuhi syarat

\section{DAFTAR RUJUKAN}

Akbar. 2003. Reformasi Pendidikan Nasional. Magelang. Indonesia Tera

Badan Penelitian dan Pengembangan. 1999. Institute for Management Development (IMD). Jakarta: Departemen Pendidikan Nasional

Depdiknas. 2003. Pembinaan Profesionalisme Tenaga Pengajar. Jakarta. Direktorat Jenderal Pendidikan Dasar dan Menengah 
Gunawan, Ary. H.. 1995. Kebijakan-Kebijakan Pendidikan di Indonesia. Jakarta: Bina Aksara.

International Educational Achievement (IEA). 2000. Jurnal Provitae. Yayasan Obor Indonesia. ISSN 02164485

OECD. 2006. Assessing Scientific, Reading, and Mathematical Literacy: A Frame Work for Programme for International Student Assessment (PISA) 2006. [online].Tersedia:www://http:oecd.org/bo okshop [13 Januari 2015]

Peraturan Pemerintah Nomor 19 tahun 2005 tentang Standar Pendidikan Nasional

Pusat Penelitian Pendidikan UM. 2003. Mutu pada SMK atau MA, Laporan Akhir Monitoring dan Evaluasi Independen Proyek Peningkatan Mutu Pendidikan Dasar dan Menengah Kejuruan
Pusat Penelitian dan Pengembangan (Puspendik). 2015. Penilaian yang Berkualitas untuk Pendidikan yang Berkualitas. Jakarta: Kementerian Pendidikan dan Kebudayaan

Undang-Undang Nomor 20 Tahun 2003 tentang Sistem Pendidikan Nasional

Undang-Undang No. 14 tahun 2005 tentang Guru dan Dosen

UNDP. 1999. Index Pembangunan Manusia Indonesia. UNDP, HDR 19992011

Word Competitiveness Yearbook. 2015. Global Competitiveness Report. Website url: https://en.wikipedia.org/wiki/Global_Co mpetitiveness_Report. Diakses Maret 2016 